\title{
Batatasin III Inhibits Migration of Human Lung Cancer Cells by Suppressing Epithelial to Mesenchymal Transition and FAK-AKT Signals
}

\author{
TATCHAKORN PINKHIEN ${ }^{1,2}$, NAREERAT PETPIROON ${ }^{2}$, \\ BOONCHOO SRITULARAK ${ }^{3}$ and PITHI CHANVORACHOTE ${ }^{2,4}$ \\ ${ }^{1}$ Pharmaceutical Technology (International) Program, Faculty of Pharmaceutical Sciences, \\ Chulalongkorn University, Bangkok, Thailand; \\ ${ }^{2}$ Cell-Based Drug and Health Product Development Research Unit, \\ Faculty of Pharmaceutical Sciences, Chulalongkorn University, Bangkok, Thailand; \\ ${ }^{3}$ Department of Pharmacognosy and Pharmaceutical Botany, \\ Faculty of Pharmaceutical Sciences, Chulalongkorn University, Bangkok, Thailand; \\ ${ }^{4}$ Department of Pharmacology and Physiology, Faculty of Pharmaceutical Sciences, \\ Chulalongkorn University, Bangkok, Thailand
}

\begin{abstract}
Background/Aim: Lung cancer is the leading cause of cancer-related deaths worldwide. Compound Batatasin III isolated from Dendrobium draconis Rchb.f. was tested for the possible anti-cancer activities including anti-proliferative, antimigration and invasion in human non-small lung cancer $\mathrm{H} 460$ cells. Materials and Methods: The effect of Batatasin III on viability and proliferation of $H 460$ cells was investigated by the 3-[4,5-dimethylthiazol-2-yl]-2,5diphenyl tetrazoliumbromide (MTT) assay. Migration and invasion assays were performed. Filopodia formation was determined by phalloidin-rhodamine staining. The hallmark signaling proteins in regulation of epithelial to mesenchymal transition (EMT), proliferation, and migration were determined by western blot analysis. Results: Batatasin III at concentrations lower than $100 \mu \mathrm{M}$ has no cytotoxic effects. The compound at 25-100 $\mu \mathrm{M}$ exhibited antiproliferative activity at $48 \mathrm{~h}$ after treatment. Regarding cell motility, Batatasin III decreased migration and invasion of cells. Filopodia were found to be significantly reduced in Batatasin III treated cells. These effects correlated with the results from
\end{abstract}

Correspondence to: Dr. Pithi Chanvorachote, Department of Pharmacology and Physiology, Faculty of Pharmaceutical Sciences, and Cell-based Drug and Health Product Development Research Unit, Chulalongkorn University, Bangkok, Thailand. Tel: +66 22188285, Fax: +66 22188340, e-mail: pithi_chan@yahoo.com and Dr. Nareerat Petpiroon, Cell-based Drug and Health Product Development Research Unit, Chulalongkorn University, Bangkok, Thailand, e-mail: petpiroon_bright@hotmail.com

Key Words: Batatasin III, migration, invasion, lung cancer, epithelial to mesenchymal transition, FAK, AKT. western blot analysis showing that the phosphorylation of focal adhesion kinase on Try397 (p-FAK (Try397)), the active protein kinase $B(A K T)$, and cell division cycle 42 (CDC42) were significantly reduced. Besides, Batatasin III significantly suppressed EMT indicated by the decrease of $N$-cadherin and Vimentin, and up-regulation of E-cadherin. Conclusion: Batatasin III has anti-cancer activities; inhibits cancer migration and invasion by suppressing EMT. Our findings establish Batatasin III as a potential compound for further studies aimed at finding a better, more effective treatment approach for lung cancer.

Lung cancer is one of the most common cancers having a significant impact on public health, worldwide. Due to the problem of drug resistance frequently found in lung cancer patients, research currently focuses on novel drug discovery and efficacy $(1,2)$. The scientists are always in search for new compounds to help fighting cancer. Their aim is not only killing cancer cells, cancer therapeutic was but also including to prevent cancer metastasis by inhibiting motility of cancer cells. Cell migration is a common cancer cell characteristic also implicated in the pathophysiology of many diseases. The ability of cancer cells to migrate is an important hallmark of cancer metastasis (3). The metastasis cascade is a multistep process consisting of five components: local migration and invasion, intravasation, circulation, extravasation, and colony formation at secondary sites (4). Cancer cells can spread in a variety of ways: the most common pathway is tumor extending in continuity beyond the organ or structure of origin and it is one of the reasons for the resultant mortality of patients with cancer. 
Chemical structure of Batatasin III, one of stilbenoids, isolated from Dendrobium draconis Rchb.f. (5) is shown in Figure 1. Generally, Dendrobium species (Orchidaceae) have been used as health foods and previous studies Batatasin III was tested in vitro for cytotoxicity against A549 (non-small cell lung adenocarcinoma), SKOV-3 (ovarian cancer cells), SK-MEL-2 (skin melanoma), and HCT15 (colon cancer cells) using the sulforhodamine $\mathrm{B}$ bioassay with $\mathrm{IC}_{50}$ values of 17.92 to $24.51 \mu \mathrm{M}$ (6). Other substances isolated from Dendrobium draconis Rchb.f. sush as Gigantol were found to significantly reduce, at non-toxic concentrations, anchorageindependent growth and survival of the cancer cells (7). Moreover, Gigantol suppressed epithelial to mesenchymal transition (EMT) in non-small cell lung cancer H460 cells (8) and also inhibited motility of H292 lung cancer cell line (9). This evidences leads to the hypothesis that Batatasin III may be able to inhibit metastasis of cancer cells.

However, the pharmacological effects of Batatasin III for cancer therapeutics are still unknown. In this study, the antimigratory effects of Batatasin III from Dendrobium draconis Rchb.f. were examined Non-small cell lung cancer H460 cells (H460 cells) were exposed to different concentrations of Batatsin III, and then cell viability, proliferation and migration were determined. Also, we investigated the underlying pathways with respect to migration. Our study might provide new insight into the prevention and treatment of lung cancer.

\section{Materials and Methods}

Materials. H460 cells were purchased from the American Type Culture Collection (Manassas, VA, USA). Penicillin, streptomycin, glutamate, and phosphate-buffered saline (PBS) were purchased from GIBCO (Grand Island, NY, USA). Methanol, ethanol and dimethyl sulfoxide (DMSO) were purchased from Sigma-Aldrich (St. Louis, MO, USA). Antibodies to Focal Adhesion Kinase (FAK), phosphorylation of Focal Adhesion Kinase on Try397 (p-FAK (Try397)), Protein Kinase B (AKT), phosphorylation of Protein Kinase B on Ser473 (p-AKT (Ser473)), Cell Division Cycle 42 (CDC42), E-Cadherin, N-Cadherin, Vimentin, $\alpha$-Tubulin and specific horseradish peroxidase (HRP) link secondary antibody were obtained from Cell Signaling Technology, Inc. (Danvers, MA, USA). Batatasin III was extracted from Dendrobium draconis Rchb.f. using methanol extraction (5).

Cell culture conditions. H460 cells was cultured with Roswell Park Memorial Institute 1640 medium supplemented with $10 \%$ fetal bovine serum (FBS), $2 \mathrm{mM}$ L-glutamine and 100 units $/ \mathrm{ml}$ penicillin and streptomycin at $37^{\circ} \mathrm{C}$ in a humidified atmosphere of $5 \% \mathrm{CO}_{2}$. Cells were seeded as recommended by the supplier and split at $80 \%$ confluence.

Cell viability assay. The 3-[4,5-dimethylthiazol-2-yl]-2,5diphenyl tetrazoliumbromide (MTT) assay was performed to determine the effect of Batatasin III on the cellular viability of H460 cells. Briefly, approximately $1 \times 10^{4}$ cells/well were plated in 96 -well plates and kept

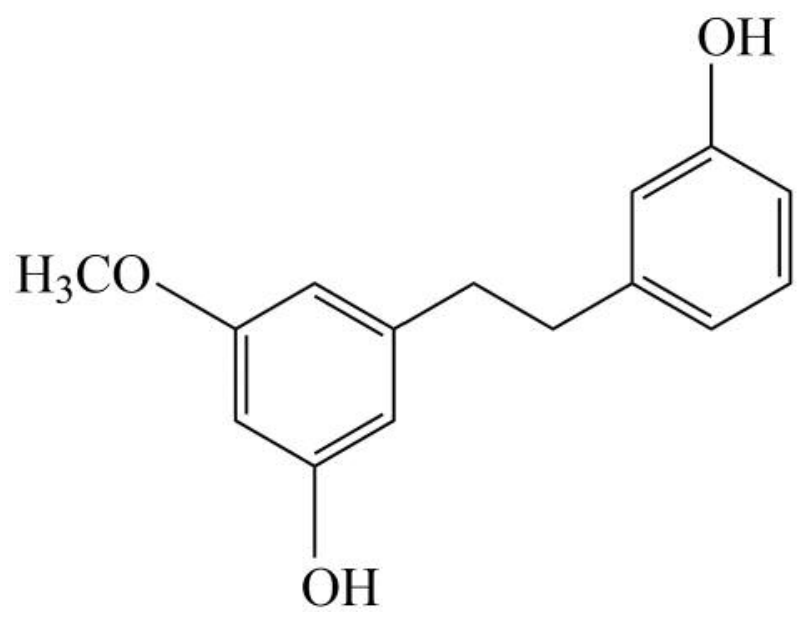

Figure 1. Structure of Batatasin III.

in an incubator at $37^{\circ} \mathrm{C}$ under the previously described cell culture conditions. After overnight incubation to allow adherence, the cells were treated with different concentrations of Batatasin III $(10 \mu \mathrm{M}$ to $100 \mu \mathrm{M}$ ) in fresh medium for $24 \mathrm{~h}$. Each treatment at this time point was assayed in at least in triplicate. At the stipulated time following treatment with Batatasin III, the medium was aspirated and MTT ( $4 \mathrm{mg} / \mathrm{ml}$ stock solution in $1 \times \mathrm{PBS}$ ) was added to each well of the $96-$ well culture plate. Incubation was continued at $37^{\circ} \mathrm{C}$ for additional $4 \mathrm{~h}$, then supernatants were discarded, and purple-colored precipitates of formazan were dissolved in $100 \mathrm{ml}$ of DMSO. The color absorbance of each aliquot was recorded at $570 \mathrm{~nm}$ with a microplate reader and repeated three times. The cytotoxic effect was expressed as the percentage cell viability compared to that of non-treated cells.

Cell proliferation assay. To evaluate proliferative effects, $\mathrm{H} 460$ cells were seeded at a density of $2 \times 10^{3}$ cells/well in 96-well plates and treated with Batatasin III $(10 \mu \mathrm{M}$ to $100 \mu \mathrm{M})$ for 0,24 and $48 \mathrm{~h}$. Next, cell proliferation was determined through incubation with MTT $(4 \mathrm{mg} / \mathrm{ml}$ stock solution in $1 \times \mathrm{PBS})$ for $4 \mathrm{~h}$ at $37^{\circ} \mathrm{C}$, after which the optical densities (OD) of the formazan products were measured at $570 \mathrm{~nm}$ using a microplate reader (Anthros, Durham, $\mathrm{NC}$, USA). The proliferation rates were determined using the following equation: OD at indicated time/OD at time 0 . The relative proliferation rates were determined by comparing the proliferation rates of treated cells with those of untreated control cells.

Filopodia detection. Cells were washed with phosphate buffer saline (PBS) and fixed with 4\% paraformaldehyde in PBS for $10 \mathrm{~min}$ at room temperature. Afterwards, cells were permeabilized by $0.1 \%$ Triton-X100 in PBS for 4 min, washed with PBS three times, and blocked with $0.2 \%$ bovine serum albumin (BSA) for $30 \mathrm{~min}$ as described elsewhere. After washing, cells were incubated with rhodamine-phalloidin in PBS for $30 \mathrm{~min}$ and rinsed three times. Images of cells stained with rhodamine-labeled phalloidin were taken under a fluorescence microscope (Olympus IX51 with DP70).

Wound scratch assay for cell motility determination. H460 cells $\left(2 \times 10^{5}\right.$ cells $\left./ \mathrm{ml}\right)$ were seeded in a 24 -well tissue culture plate and grown to $90 \%$ confluence. After aspiration of the medium, the 
A

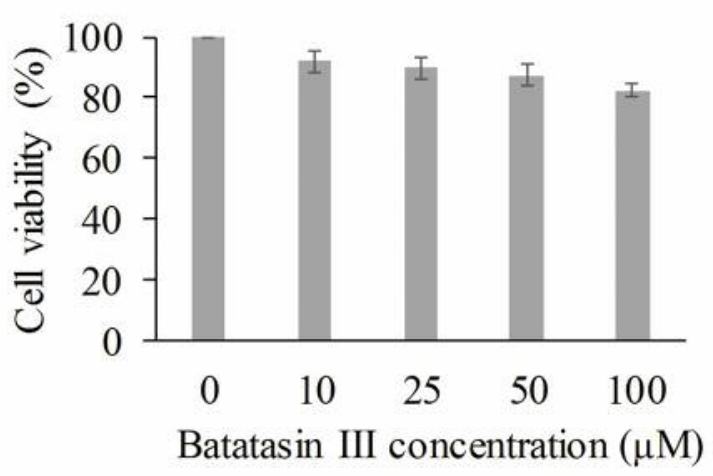

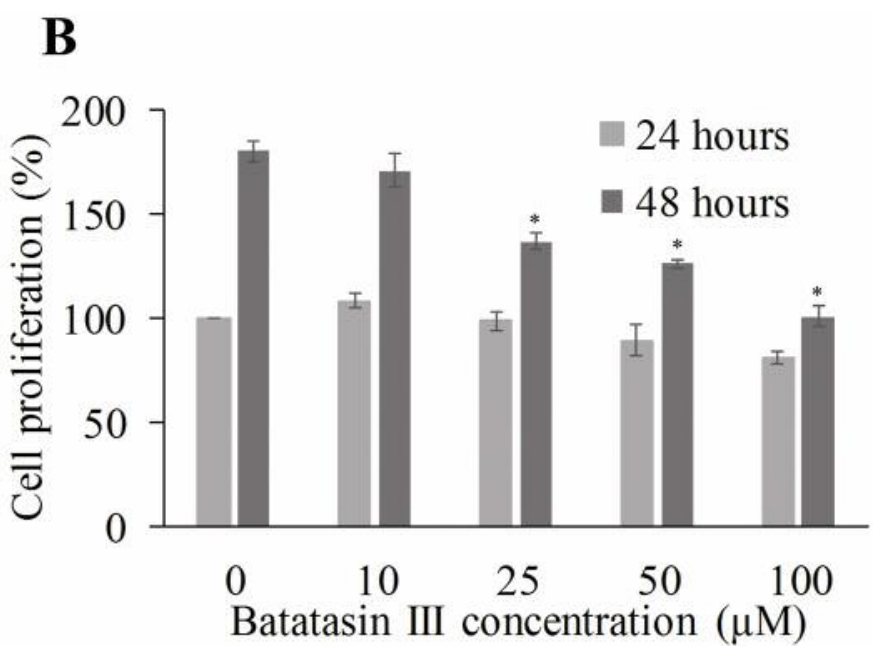

C

\section{Bright field}

Hoechst 33342

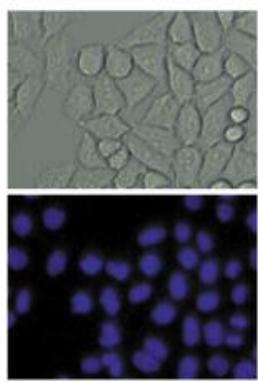

0

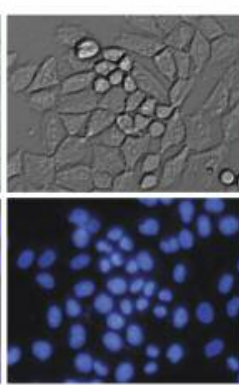

10

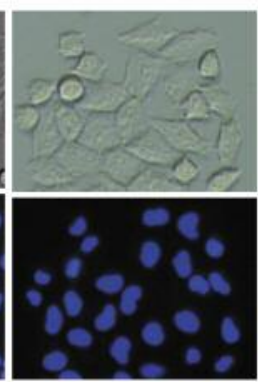

25

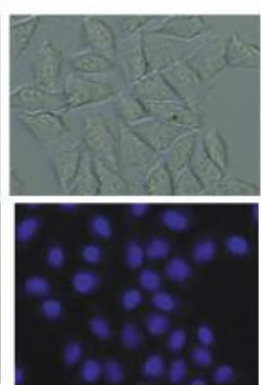

50

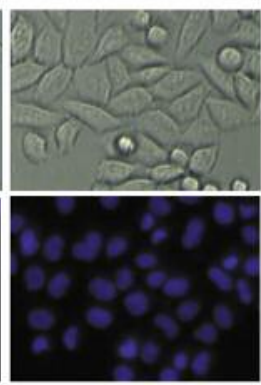

100

\section{Batatasin III concentration $(\mu \mathrm{M})$}

Figure 2. Viability of non-small cell lung cancer H460 cells in response to 10, 25, 50 and $100 \mu M$ Batatasin III treatment for 24 h (A) and proliferation of the cell at 24 and $48 \mathrm{~h}(\mathrm{~B})$. Cell viability was evaluated using 3-[4,5-dimethylthiazol-2-yl]-2,5 diphenyl tetrazoliumbromide (MTT) assays. Data represent mean $\pm S D(n=3) . * p<0.05$ versus non-treated control. After 24 h the cells were stained with Hoechst 33342 and visualized by florescence microscopy $(C)$.

center of the cell monolayers was scraped with a sterile micro-pipet tip to create a denuded zone (gap) of constant width. Subsequently, cellular debris was washed with PBS, and H460 cells were exposed to various concentrations of Batatasin III $(10 \mu \mathrm{M}$ to $100 \mu \mathrm{M})$. Wound closure was monitored and photographed at 0,24 and $48 \mathrm{~h}$ with a Nikon inverted microscope. To quantify the migrated cells, pictures of the initial wounded monolayers were compared with the corresponding pictures of cells at the end of the incubation. Artificial lines fitting the cutting edges were drawn on pictures of the original wounds and overlaid on the pictures of cultures after incubation. Cells that had migrated across the white lines were counted in four random fields from each triplicate treatment.

Cell invasion assay. Transwell invasion assay was performed using a Boyden chamber (BD Bioscience, MA, USA). To this end, the transwell membrane was coated with Matrigel and cells were seeded at a density of $2 \times 10^{4}$ cells/well in the upper chamber supplemented with RPMI-1640 serum free medium, while RPMI-1640 complete medium containing $10 \%$ FBS was added to the lower chamber compartment. After incubation at $37^{\circ} \mathrm{C}$, the non-invaded cells in the upper chamber were gently removed with a cotton swab, whereas the cells that had moved to the lower compartment of the membrane were fixed with cold absolute methanol for $10 \mathrm{~min}$ and stained with 10 $\mu \mathrm{g} / \mathrm{ml}$ Hoechst 33342 for $10 \mathrm{~min}$. Finally, these cells were visualized and captured using a fluorescence microscope (Olympus IX5; 20x).

Western blotting analysis. Migration proteins were detected by western blot analysis. H460 cells were treated with 50 and $100 \mu \mathrm{M}$ of Batatasin III for $24 \mathrm{~h}$ and harvested. All cells were collected by scraping and were lysed with lysis buffer for $45 \mathrm{~min}$. The protein concentrations were measured with the Pierce ${ }^{\mathrm{TM}}$ BCA Protein Assay Kit (Pierce, Rockford, IL, USA). The resultant lysates were boiled at $95^{\circ} \mathrm{C}$ for $5 \mathrm{~min}$ with Laemmli loading buffer and were subsequently loaded onto a $10 \%$ SDS-polyacrylamide gel. After 


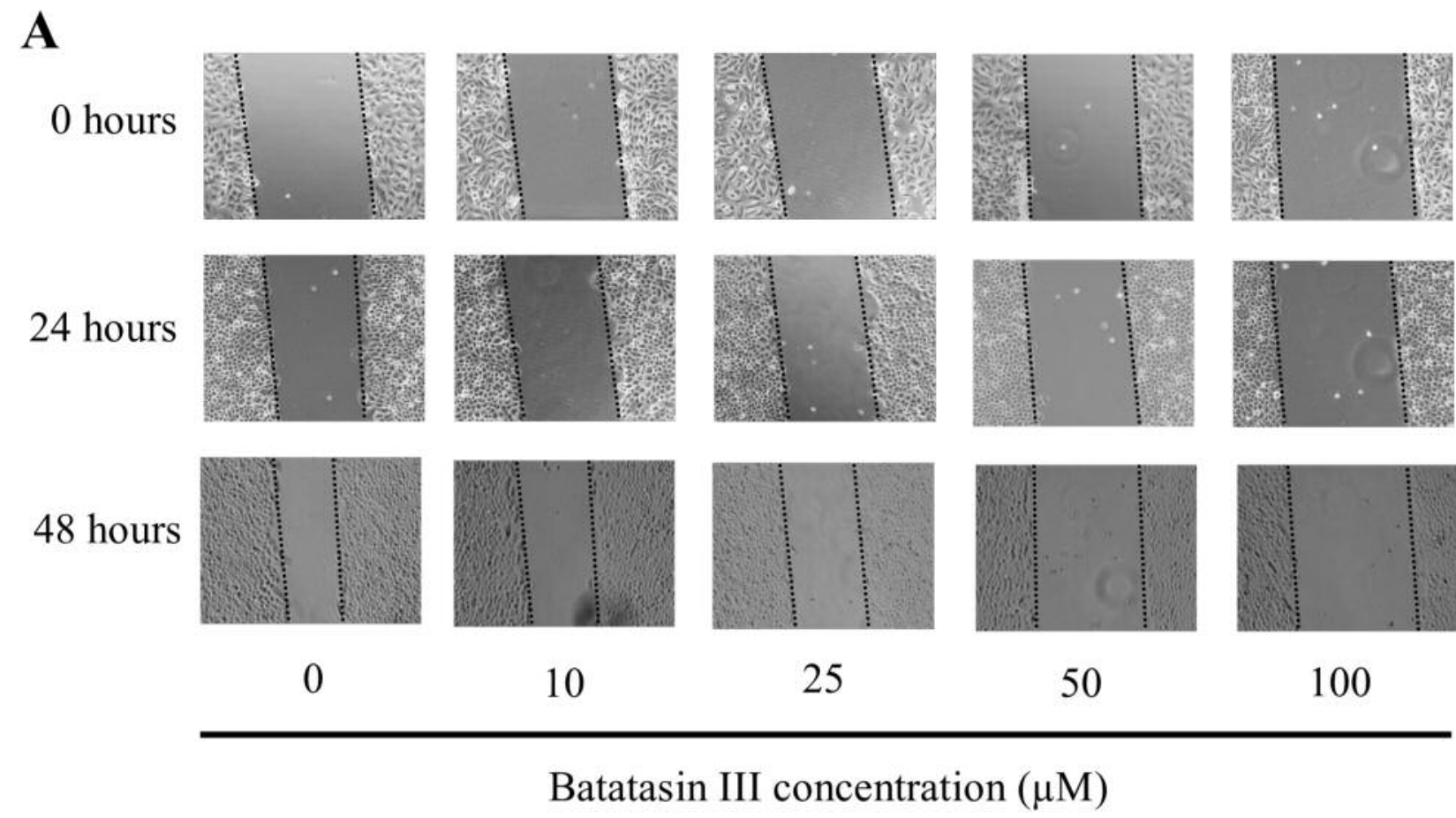

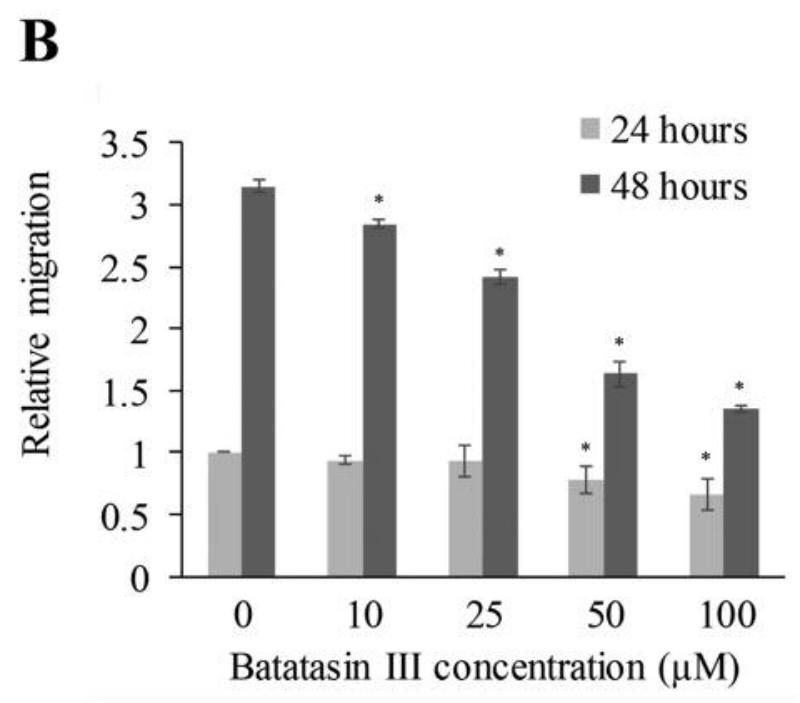

separation, the proteins were transferred to nitrocellulose membrane (Bio-Rad, Hercules, CA, USA). The membranes were blocked for $1 \mathrm{~h}$ in $5 \%$ non-fat dry milk in TBST (25 mM Tris- $\mathrm{HCl}(\mathrm{pH} \mathrm{7.5),}$ $125 \mathrm{mM} \mathrm{NaCl}$ and $0.05 \%$ Tween 20) and incubated overnight with the propriate primary antibodies at $4^{\circ} \mathrm{C}$. The membranes were washed twice with TBST for $10 \mathrm{~min}$ and incubated with horseradish peroxidase-coupled isotype-specific secondary antibodies for $1 \mathrm{~h}$ at room temperature. The immune complexes were detected by enhancement with a chemiluminescence substrate (Pierce, Rockford, IL, USA) and quantified using analyst/PC densitometry software (Bio-Rad, Hercules, CA, USA).
Figure 3. Migration behavior of non-small cell lung cancer $H 460$ cells. Cells were treated with 10, 25, 50 and $100 \mu \mathrm{M}$ Batatasin III for $24 \mathrm{~h}$ and subjected to wound scratch assay. Representative photographs of migrating cells that received either control or Batatasin III treatment (A). The relative cell migration of non-small cell lung cancer $H 460$ cells are shown in each Batatasin III concentration (B). Data represent mean $\pm S D(n=3) . * p<0.05$ versus non-treated control.

Statistical analysis. Data from three or more independent experiments are presented as the mean \pm standard deviation (SD). Multiple comparisons for significant differences between multiple groups were performed using analysis of variance (ANOVA), followed by individual comparisons with Scheffe's post-hoc test. Statistical significance was considered at $p<0.05$.

\section{Results}

Effect of Batatasin III on cell viability and proliferation. The ability of Batatasin III to reduce cancer cell viability and 


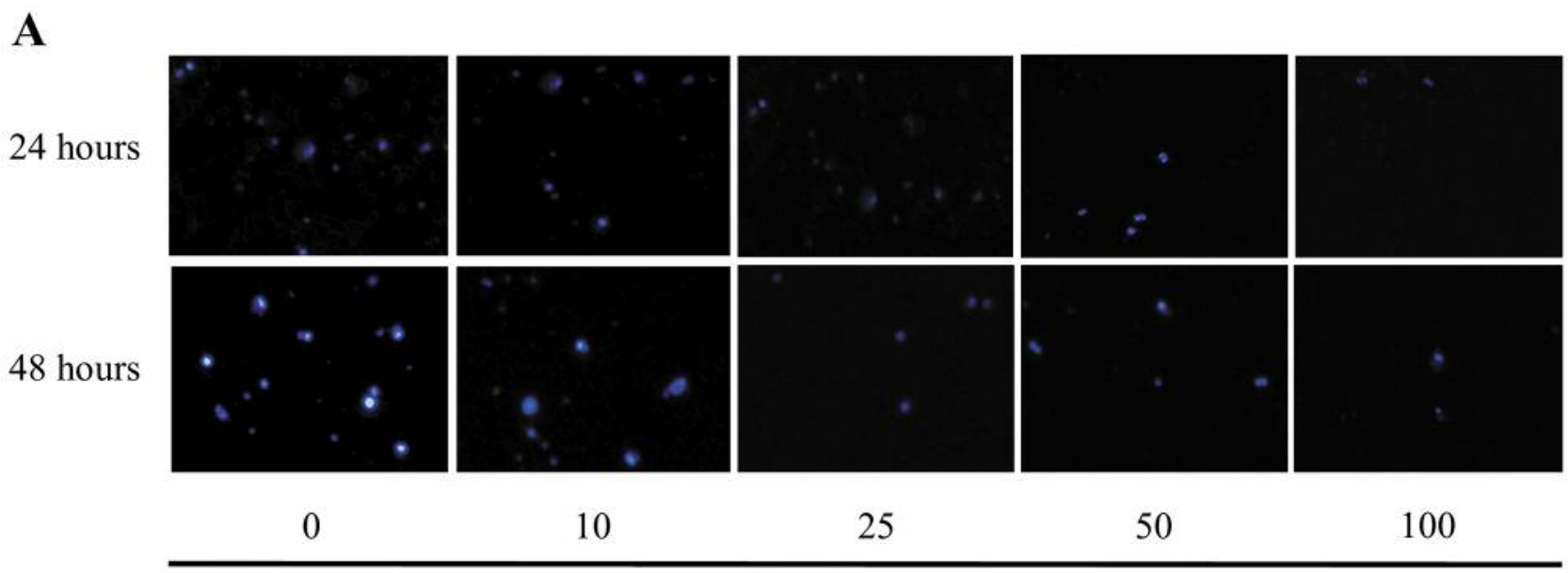

Batatasin III concentration $(\mu \mathrm{M})$

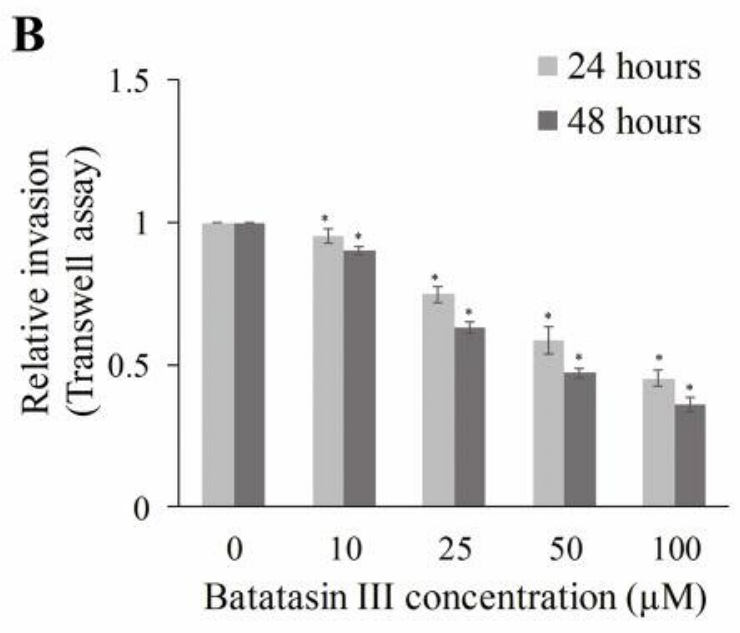

inhibiting cell division were determined in human lung cancer H460 cells by MTT assay. As shown in Figure 2A, cell viability was not altered in response to the compound at the concentrations up to $100 \mu \mathrm{M}$ for $24 \mathrm{~h}$ treatment as compared to the untreated control. Regarding proliferation, the cells at low seeding density were allowed to grow in the absence or presence of the Batatasin III for 24-48 h. Figure 2B shows that Batatasin III at concentrations of $10-100 \mu \mathrm{M}$ did not significantly alter cell proliferation at $24 \mathrm{~h}$. However, the proliferation rate of cells treated with 25-100 $\mu \mathrm{M}$ Batatasin III for $48 \mathrm{~h}$ was significantly decreased in dose-dependent manner. Based on these experiments, the range of concentrations $10-100 \mu \mathrm{M}$ was selected for the investigation of anti-migration and invasion as these concentrations had neither toxic nor proliferative effects.

Effect of batatasin III on migration and invasion. The effect of the compound on cancer cell movement was next evaluated
Figure 4. Effect of Batatasin III on cell invasion. After treating with subtoxic concentrations of Batatasin III for 24 and $48 \mathrm{~h}$, cells were subjected to invasion assay and stained with Hoechst 33342 and examined under fluorescent microscopy (A). Relative invasion in $\mathrm{H} 460$ cells treated with Batatasin III compared with control (B). Data represent mean $\pm S D(n=3) . * p<0.05$ versus non-treated control.

by the wound healing assay. Batatasin III significantly reduced cell migration at the concentrations 50-100 $\mu \mathrm{M}$ and 10-100 $\mu \mathrm{M}$ for 0,24 or $48 \mathrm{~h}$ of treatment as compared with the control. Using pre-migration and post-migration images of cells, the gap closure was calculated at every concentration. Figure 3A shows the effect of Batatasin III on cell motility and migration. Quantification of the results is presented in Figure $3 \mathrm{~B}$, Batatasin III decreases cell migration in a dose-dependent manner. Further, the effect of the compound on cancer cell invasion was evaluated by Boyden chamber-based invasion assay as described in Materials and Methods. The cells were allowed to invade through the Matrigel layer and membrane for 24-48 h, and the number of invaded cells was determined. Relative invasion is shown in Figures 4A and B. The Results showed that treatment of the cells with non-toxic concentrations of Batatasin III significantly suppressed lung cancer cell invasion at both times. 


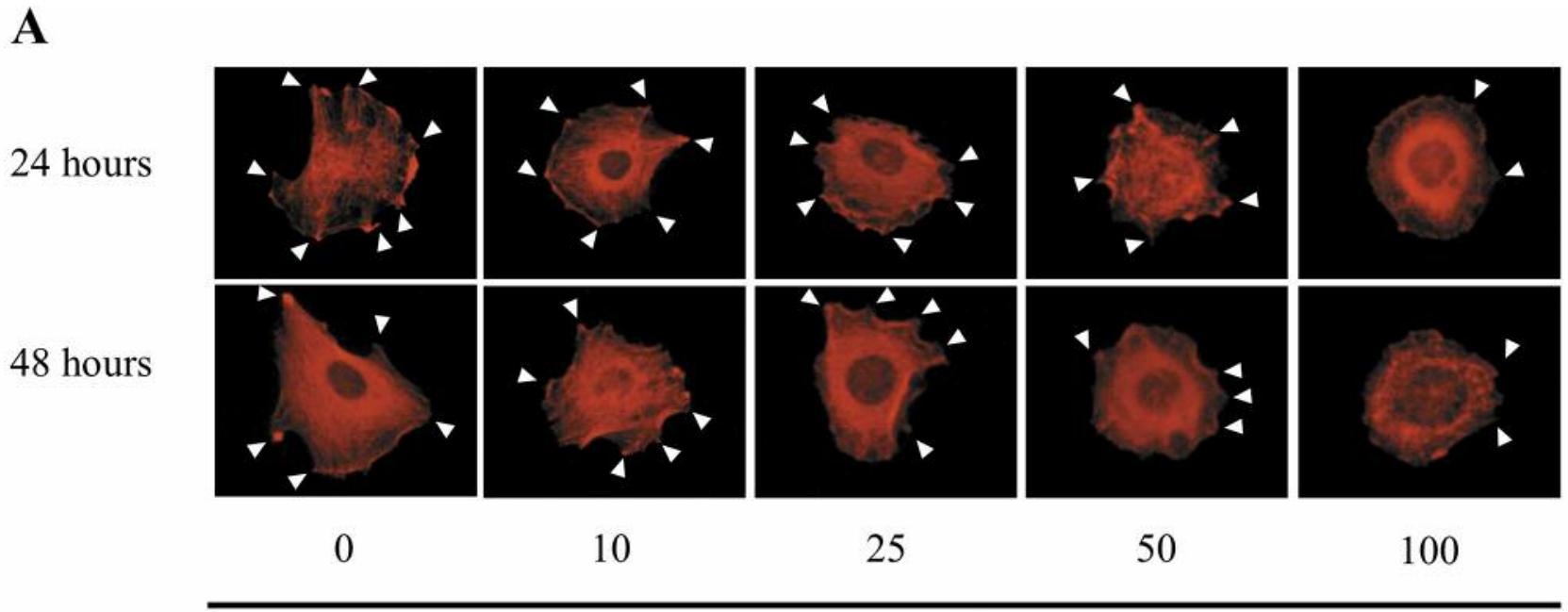

Batatasin III concentration $(\mu \mathrm{M})$

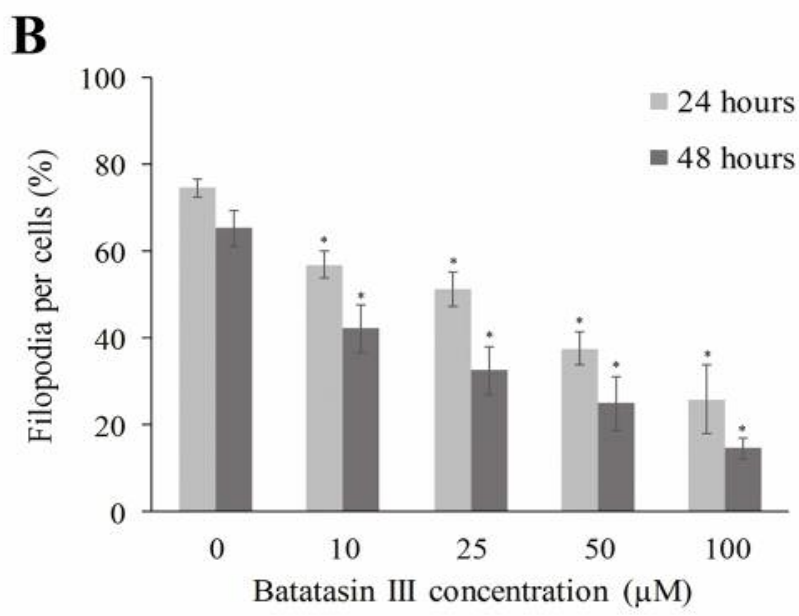

Batatasin III reduces Filopodia formation of lung cancer cells. Cellular protrusions called filopodia has been shown to be essential for cell migration and invasion, and highly motile cells frequently exhibit increased filopodia per cell. We examined filopodia formation in response to Batatasin III treatment. The cells were treated with various concentrations of Batatasin III $(0-100 \mu \mathrm{M})$ for $24-48 \mathrm{~h}$ and stained with phalloidin for filopodia detection. Under fluorescence microscope, we observed that untreated control cells exhibited several membrane protrusions of filopodia (Figure 5). Interestingly, the number of filopodia per cell dramatically decreased in response to Batatasin III at 50 and $100 \mu \mathrm{M}$.

Batatasin III inhibits migratory effect through the inhibition of EMT and suppression of FAK/AKT/CDC42 pathway. Having shown that Batatasin III inhibits migration and invasion of lung cancer cells, we next investigated the possible mechanisms of
Figure 5. Effect of Batatasin III on filopodia formation. After treating with sub-toxic concentrations of Batatasin III for 24 and $48 \mathrm{~h}$, cells were stained with phalloidin-rhodamine and examined under fluorescent microscopy. Filopodia characteristic are indicated by arrow (A). Percentage of filopodia per cells in H460 cells treated with Batatasin III compared to control $(B)$. Data represent mean $\pm S D(n=3)$. *p $<0.05$ versus non-treated control.

action. In terms of EMT, the well-known EMT markers including E-cadherin, $\mathrm{N}$-cadherin, and Vimentin levels were evaluated in cells treated with Batatasin III. Results revealed that Batatasin III-treated cells exhibited an EMT suppressing effect by significantly decreasing $\mathrm{N}$-cadherin and Vimentin, and increasing expression of E-cadherin (Figure 6).

In addition, the migratory-related signaling proteins including Focal Adhesion Kinase (FAK), phosphorylated FAK at Try397 (p-FAK (Try397)), Cell Division Cycle 42 (CDC42), Protein kinase B (AKT), and phosphorylated AKT at Ser473 (p-AKT (Ser473)) were evaluated by western blot analysis. Results indicated that 50 and $100 \mu \mathrm{M}$ Batatasin III significantly decreased the levels of phosphorylated FAK and phosphorylated AKT, while it had no effect on the level of total FAK and total AKT (Figure 7A). Moreover, the CDC42 level was decreased in the Batatasin III-treated cells. The results were converted to histogram of relative protein expression 


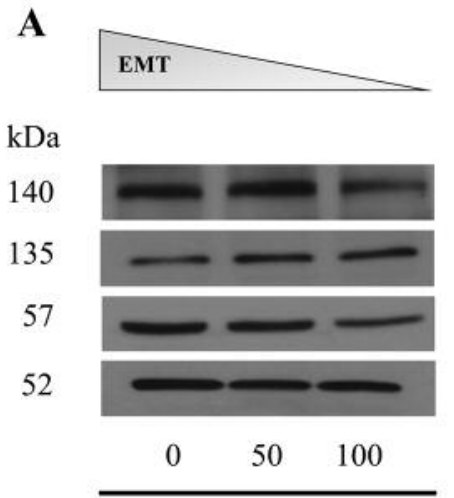

Batatasin III concentration $(\mu \mathrm{M})$

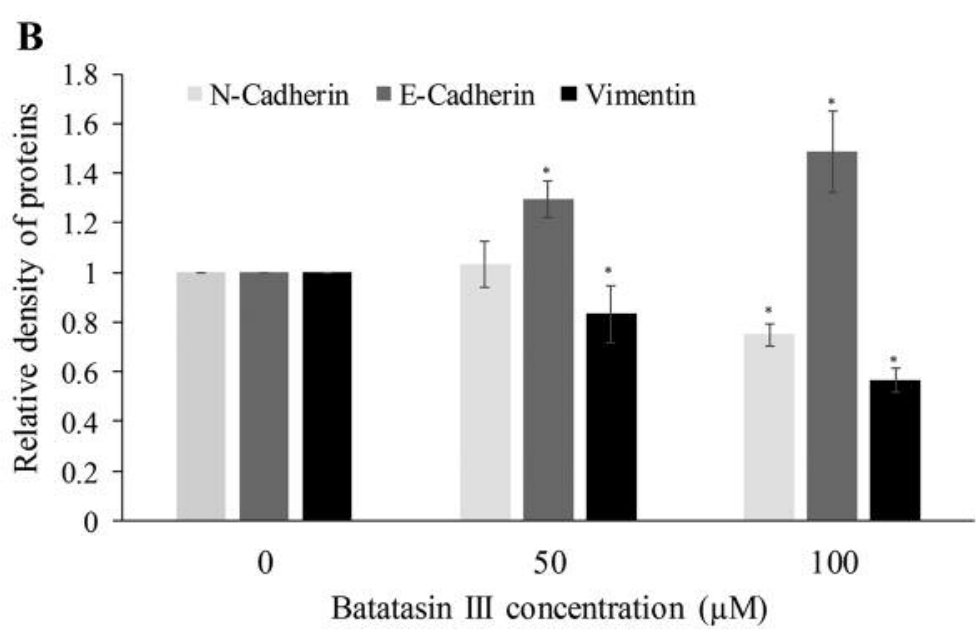

Figure 6. Effect of Batatasin III on N-cadherin, E-cadherin, and vimentin in non-small cell lung cancer $H 460$ cells. Cells were treated with 50 and

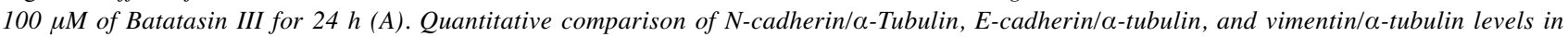
non-small cell lung cancer $H 460$ cells under different treatment concentrations were quantified by densitometry $(B)$. Data represent mean $\pm S D(n=3)$. ${ }^{*} p<0.05$ versus non-treated control.

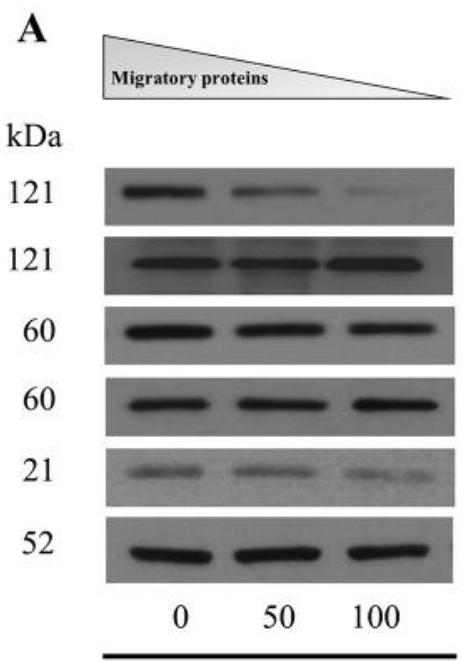

Batatasin III concentration $(\mu \mathrm{M})$
B

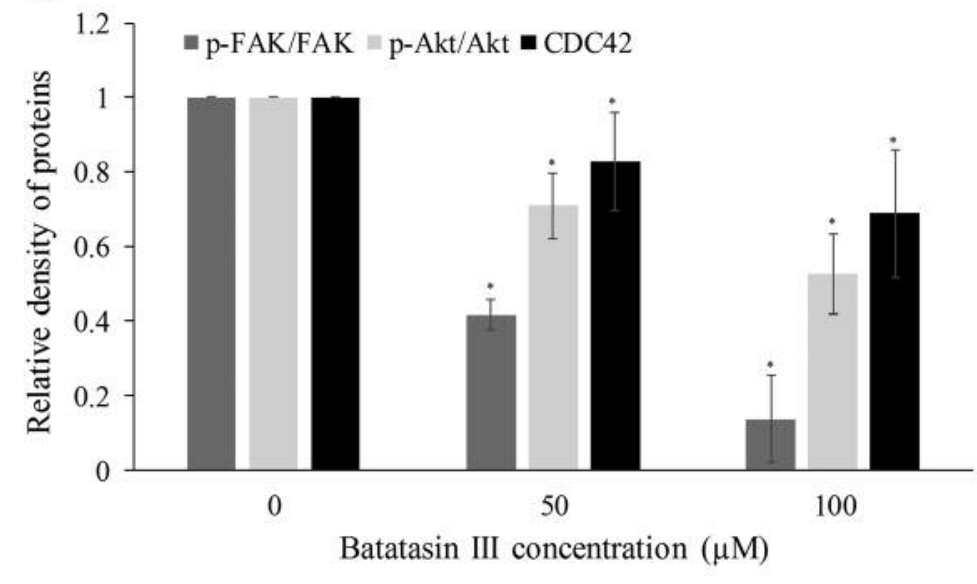

Figure 7. Effect of Batatasin III on focal adhesion kinase (FAK), protein kinase B (AKT), and cell division cycle (CDC42) in non-small cell lung cancer $H 460$ cells. Cells were treated with 50 and $100 \mu \mathrm{M}$ of Batatasin III for $24 \mathrm{~h}$ (A). Quantitative comparison of p-FAK/FAK, $p$-AKT/AKT, and CDC42/ $\alpha$-Tubulin levels in non-small cell lung cancer $H 460$ cells under different treatment concentrations were quantified by densitometry (B). Data represent mean $\pm S D(n=3) .{ }^{*} p<0.05$ versus non-treated control. $p$-FAK: phosphorylated focal adhesion kinase at Try397; FAK: focal adhesion kinase; p-AKT: phosphorylated of protein kinase B at Ser473; AKT: protein kinase B; CDC42: cell division cycle 42.

compared with $\alpha$-Tubulin (Figure 7B). These results suggest that Batatasin III could suppress motility and cell proliferation by suppressing p-FAK, p-AKT and CDC42 pathways.

These data indicated that the possible mechanism of action of this compound against lung cancer cell migration and invasion involves suppression of EMT as well as decrease of the migration regulatory $\mathrm{FAK} / \mathrm{AKT} / \mathrm{CDC} 42$ pathway.

\section{Discussion}

Cell migration is an important process for the metastasis of cancer cells, and was shown to be critical enhancing factors of high mortality in lung cancer patients. Herein, we have revealed for the first time that the pure Batatasin III isolated from Dendrobium draconis Rchb.f., has anti-cancer activities 


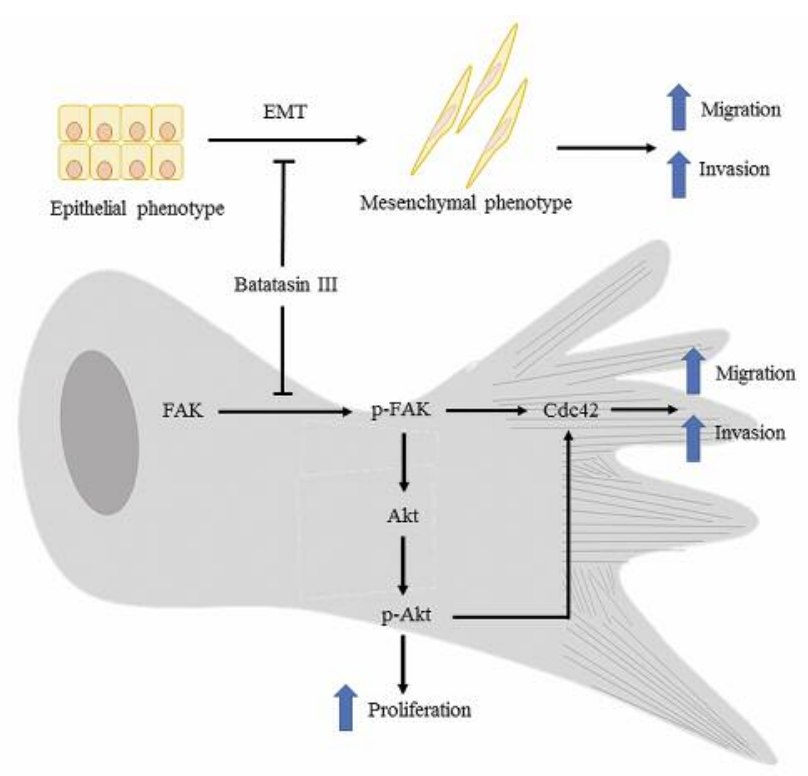

Figure 8. Schematic illustration showing the anti-migratory mechanism of Batatasin III. Batatasin III suppresses cell migration by suppressing EMT and FAK/AKT/CDC42 pathway.

by inhibiting cell migration, invasion, and proliferation. Prior to migration experiments, dose-dependent cell viability tests were performed to determine a range of working concentrations that maintain viability over $80 \%$. Avoiding toxicity to cells was crucial to selectively examine antimigratory effects of the compound. Our results indicated that Batatasin III significantly inhibited the migration of lung cancer cells in a dose-dependent manner at 24 and $48 \mathrm{~h}$. As at this concentration and time setting, the cell viability was not affected by the treatment, the migration inhibitory effect of Batatasin III was not due to the toxicity effect. FAK and AKT are known to play a role in the regulation of cancer cell migration $(10,11)$. We thus investigated the effect of Batatasin III on such signaling proteins. FAK's effect on cell motility was shown to involve its downstream AKT. Stimulation by fibronectin of A549 lung epithelial cell migration resulted in increased phosphorylation of FAK and its downstream targets AKT. Consistent with this observation, depletion of FAK by siRNA resulted in the inhibition of AKT activity (10). Additionally, AKT plays an essential role in cell survival, migration, proliferation, cell cycle progression, angiogenesis, and self-renewal of stem cells (11). Thus, the reduction of phosphorylated FAK and AKT may mediate the inhibitory effect of Batatasin III on migration of lung cancer cells as show in Figure 7.

Our results relate to pharmacological effects of compounds that derived from Dendrobium species. More evidence suggest that several natural compounds have the ability to inhibit cell migration in various cancer cells via AKT including phenolic compounds from Dendrobium species. Especially, moscatilin, Dendrobium brymerianum isolated compounds showed inhibition of migration of human breast cancer MDA-MB-231 cells via AKT- and Twist-dependent pathways (12). Gigantol, a bibenzyl compound extracted from Dendrobium draconis, has been shown to suppress EMT and filopodia formation and decrease the level of migration in H460 lung cancer cells via AKT and CDC42 $(8,9)$. Herein our new results showed that Batatasin III also inhibited cell migration and invasion by suppressing EMT. Other Dendrobium brymerianum isolated compounds, lusianthridinn, and dendrolorin have been reported to inhibit migration of $\mathrm{H} 460$ cells across the wound space in a time-dependent manner (13). All the reported results lead to the hypothesis that Batatasin III may be able to inhibit the cell migration in cancer cells.

In addition, the reduction of phosphorylated AKT play a pivotal role in inhibiting proliferation of lung cancer cells. AKT regulation is important in both migration and proliferation. Previous studies suggest that compounds, which are able to block AKT pathway have effected in cell survival, proliferation, migration and differentiation, contributing to tumorigenesis and tumor metastasis (14). These results indicated that Batatasin III suppressed lung cancer cells proliferation through the reduction in the levels of phosphorylated AKT.

Moreover, phosphorylated FAK has been shown to induce cell protrusions via CDC42 (15). Protrusion is a critical step in cell migration. CDC42-GTPases is a member of the highly conserved Rho family and acts downstream of phosphorylated FAK. CDC42-GTPases have been shown in various cell types to regulate actin polymerization, cell polarity, filopodia formation and forward protrusions (16). Expression of the dominant-negative CDC42 confirmed the role of these GTPases in the actin reorganization that is required to form filopodia (17). Reduced filopodia forming at the edge of cells was observed in lung cancer cells treated with Batatasin III for $24 \mathrm{~h}$. The results clearly confirmed with the dose-dependent decreasing of CDC42 protein in Figure 7.

Other studies examining the effect of Batatasin III to cancer cells found that Batatasin III from Orchidaceae inhibits growth of K562 and HL-60 (human leukaemia cell lines), A549 (human lung adenocarcinoma), BEL-7402 (human hepatoma), SGC-7901 (human stomach cancer), SKOV-3 (ovarian cancer cells), SK-MEL-2 (skin melanoma), and HCT15 (colon cancer cells) $(6,18)$. Our results suggest clearly that the pathway of FAK, AKT and CDC42 is involved in the effect of Batatasin III on the migration and proliferation of $\mathrm{H} 460$ cells (Figure 7). This is valuable information that highlights the role of Batatasin III in lung cancer therapeutics. 


\section{Conclusion}

In conclusion, Batatasin III from Dendrobium draconis Rchb.f. has promising anti-cancer properties by inhibiting cell proliferation, migration and invasion by suppressing EMT and FAK/AKT/CDC42 pathway. These findings have pointed out that Batatasin III could be a drug candidate or lead drug for the development of novel anti-cancer approaches (Figure 8).

\section{Conflicts of Interest}

The Authors declare there is no conflict of interest with regard to this study.

\section{Acknowledgements}

This study was supported by a grant for International Research Integration: Chula Research Scholar, Ratchadaphisek Somphot Endowment Fund and Ratchadaphisek Somphot Fund for Postdoctoral Fellowship, Chulalongkorn University.

\section{References}

1 Zhang W, Lei P, Dong X and Xu C: The new concepts on overcoming drug resistance in lung cancer. Drug Des Devel Ther 8: 735-744, 2014.

2 Ma X and Yu H: Global Burden of Cancer. Yale J Biol Med 79: 85-94, 2006

3 Geho DH, Bandle RW, Clair T and Liotta LA: Physiological mechanisms of tumor-cell invasion and migration. Physiology (Bethesda, Md) 20: 194-200, 2005.

4 Mina LA and Sledge GW Jr.: Rethinking the metastatic cascade as a therapeutic target. Nat Rev Clin Oncol 8: 325-332, 2011.

5 Sritularak B, Anuwat $\mathrm{M}$ and Likhitwitayawuid K: A new phenanthrenequinone from Dendrobium draconis. J Asian Nat Prod Res 13: 251-255, 2011.

6 Woo KW, Park JE, Choi SU, Kim KH and Lee KR: Phytochemical Constituents of Bletilla striata and Their Cytotoxic Activity. Nat Prod Sci 20: 91-94, 2014.

7 Bhummaphan N and Chanvorachote P: Gigantol Suppresses Cancer Stem Cell-Like Phenotypes in Lung Cancer Cells. Evid Based Complement Alternat Med 2015: 10, 2015.

8 Unahabhokha T, Chanvorachote P, Sritularak B, Kitsongsermthon $\mathrm{J}$ and Pongrakhananon V: Gigantol Inhibits Epithelial to Mesenchymal Process in Human Lung Cancer Cells. Evid Based Complement Alternat Med 2016: 10, 2016.
9 Charoenrungruang S, Chanvorachote P, Sritularak B and Pongrakhananon V: Gigantol, a Bibenzyl from Dendrobium draconis, Inhibits the Migratory Behavior of Non-Small Cell Lung Cancer Cells. J Nat Prod 77: 1359-1366, 2014.

10 Meng XN, Jin Y, Yu Y, Bai J, Liu GY, Zhu J, Zhao YZ, Wang Z, Chen F, Lee KY and Fu SB: Characterisation of fibronectinmediated FAK signalling pathways in lung cancer cell migration and invasion. Br J Cancer 101: 327-334, 2009.

11 Liao Y and Hung M-C: Physiological regulation of Akt activity and stability. Am J Transl Res 2: 19-42, 2010.

12 Pai HC, Chang LH, Peng CY, Chang YL, Chen CC, Shen CC, Teng CM and Pan SL: Moscatilin inhibits migration and metastasis of human breast cancer MDA-MB-231 cells through inhibition of Akt and Twist signaling pathway. J Mol Med (Berl) 91: 347-356, 2013.

13 Klongkumnuankarn P, Busaranon K, Chanvorachote P, Sritularak $\mathrm{B}$, Jongbunprasert $\mathrm{V}$ and Likhitwitayawuid $\mathrm{K}$ : Cytotoxic and Antimigratory Activities of Phenolic Compounds from Dendrobium brymerianum. Evid Based Complement Alternat Med : eCAM 2015: 350410, 2015.

14 Nitulescu GM, Margina D, Juzenas P, Peng Q, Olaru OT, Saloustros E, Fenga C, Spandidos D, Libra M and Tsatsakis AM: Akt inhibitors in cancer treatment: The long journey from drug discovery to clinical use (Review). Int J Oncol 48: 869-885, 2016.

15 Myers JP, Robles E, Ducharme-Smith A and Gomez TM: Focal adhesion kinase modulates $\mathrm{Cdc} 42$ activity downstream of positive and negative axon guidance cues. J Cell Sci 125: 29182929, 2012.

16 Raftopoulou $M$ and Hall A: Cell migration: Rho GTPases lead the way. Dev Biol 265: 23-32, 2004.

17 Zamudio-Meza H, Castillo-Alvarez A, Gonzalez-Bonilla C and Meza I: Cross-talk between Rac1 and Cdc42 GTPases regulates formation of filopodia required for dengue virus type- 2 entry into HMEC-1 cells. J Gen Virol 90: 2902-2911, 2009.

18 Chen Y, Xu J, Yu H, Qing C, Zhang Y, Wang L, Liu Y and Wang J: Cytotoxic phenolics from Bulbophyllum odoratissimum. Food Chem 107: 169-173, 2008.
Received May 26, 2017

Revised June 14, 2017

Accepted June 15, 2017 